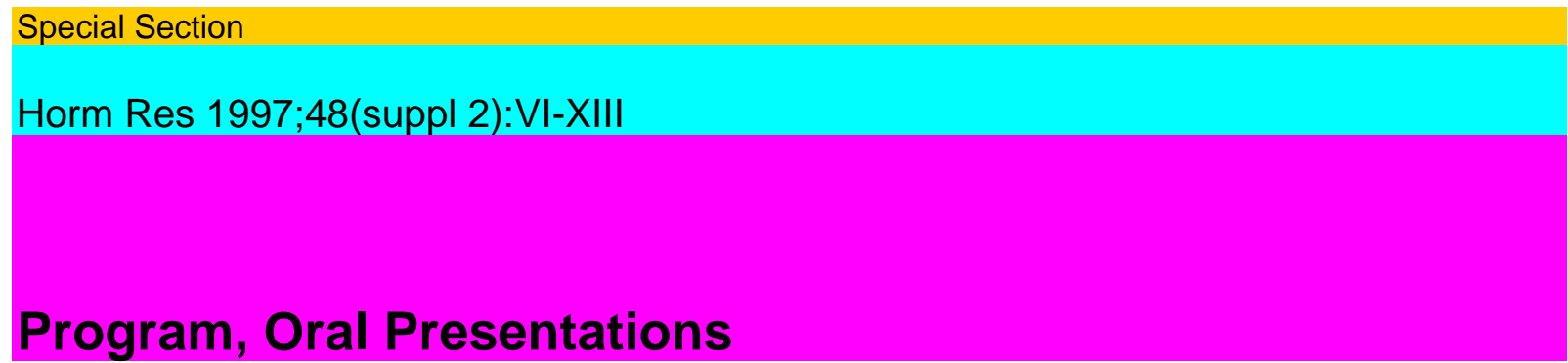

\title{
Abstract No.
}

Monday June 23 08:30-09:30

11:00-12:30

The Lawson Wilkins Lecture

GH Receptor Signalling and the Nuclear Actions of GH

Rotwein P, Thomas MJ, Lestunff C

Oregon Health Sciences University, Portland, USA

New Insights into the Role of Estrogen Synthesis and Sensitivity for Somatic Development

Estrogen Responses in Estrogen Receptor-Minus Mice

Lubahn DB, Taylor JA, Das SK, Dey SK University of Missouri, Columbia, USA

Consequences of Aromatase Deficiency and of Estrogen Receptor Dysfunction

Conte FA, Grumbach MM

University of California, San Fransisco, USA

Physiology and Structure-Function Aspects on Estrogen Receptor $\beta$

Gustafsson J-Å

Huddinge Hospital, Sweden

Identification of Novel Alternative Splicing of the 5'-End of P450arom mRNA in Peripheral

Blood Lymphocytes from Patients with Familial Aromatase Excess Syndrome and Normal

Controls

Vottero A, Chrousos GP

National Institute of Child Health, USA

IGF Binding Proteins: Biological Activity

Regulation of Carbohydrate Metabolism by IGFBPs

Baxter RC

Rolling Institute of Medical Research, NSW, Australia

Insulin-Like Growth Factor Binding Protein-Specific Proteases

Conover CA

Mayo Clinic, Rochester, USA

IGF-lndependent Actions of IGFBPs: New Concepts for Their Roles in Growth Regulation Oh Y, Yamanaka Y, Wilson E, Kim HS, Vorwerk P, Hwa V, Yang DH, Wanek D, Rosenfeld RG Oregon Health Sciences University, Portland, USA

Cellular Localization of IGFBPs in the Rat Brain following Moderate and Severe Hypoxiclschaemic Injury

Werther G, Russo VC, Butler GE, Baker NL, Beilharz EJ, Williams CE, Gluckman PD Royal Children's Hospital, Melbourne, Australia

Thyroid Function as Revealed by Genetic Disease

Genetics of Thyroid Development

Di Lauro R

Stazione Zoologica Anton, Dohrn, Italy 
The Syndrome of Resistance to Thyroid Hormone

Refetoff S, Hayashi Y, Weiss RE The University of Chicago, USA

Defects in Thyroid Hormone Biosynthesis

De Vijlder JJM, Vulsma T

University of Amsterdam, The Netherlands

Thyroid Cancer: Lessons from Chernobyl

Reiners C

University of Würzburg, Germany

10

11

12

13

VI

Abstract No.

14:00-15:30 Growth and Growth Hormone

Growth Hormone (GH) Binding Protein-Positive Laron Syndrome (LS): Two Models of GH

Resistance due to 14

Abnormal Intracellular GH Signalling

Freeth J, Whatmore AJ, Silva CM, Clayton PE RMCH, Manchester, UK

Characterization of the Alternatively Spliced Form of Human Growth Hormone Receptor (GHR) 15

Amit T, Bergman T, Dastot F, Bar-Am O, Youdim MBH, Amselem S, Hochberg Z, Rambam Medical Center, Haifa, Israel

Risk of Leukemia in Children Treated with Human Growth Hormone (GH): The National

Cooperative Growth 16 Study (NCGS) Experience

Blethen SL, Allen DB, Rundle AC, Graves D Genetech Inc, San Fransisco, USA

Cardiac Involvement in the GH Withdrawal Syndrome in Short Normal Children 17

Lampit M, Vilkas DL, Lorber A, Hochberg Z Faculty of Medicine, Haifa, Technion, Israel

Near Normalization of Final Height with Optimized Usage of Growth-Hormone in Turner

Syndrome 18

Carel JC, Mathivon L, Gendrel C, Chaussain J-L Hôpital Saint-Vincent-de-Paul, France

Final Height in Short Normal Girls Treated with Growth Hormone plus GnRH-Analogs. Further

Data on New 19 Cases and Comparison with an Untreated Control Group

Saggese G, Barsanti S, Federico G University of Pisa, Italy

Adrenal Disorders

Expression of 3-Beta Hydroxysteroid Dehydrogenase (3-BetaHSD) in Human Prepubertal

Adrenal Tissue as 20

a Function of Age

Be $1 / 8$ orosky A, Dardis A, Saraco S, Rivarola MA Hospital de Pediatria Garrahan, Argentina

Two-Year Experience with Flutamide, Testolactone, and Reduced Hydrocortisone Dose in the

Treatment 21

of Congenital Adrenal Hyperplasia

Merke DP, Jones JV, Barnes KM, Hill KM, Cutler GB National Institutes of Health, USA

Membrane Binding and Function of Wild-Type and Mutated P450c21 22

Lajic S, Nikosjkov A, Wedell A Karolinska Hospital, Stockholm, Sweden

Why the $21-\mathrm{H} \gamma$ droxylase and C4 Genes Are Linked23 
Zhang G, Rodriguez H, Fu GK, Miller WL University of California, USA

Molecular Analysis of DAX-1 Gene in Patients with X-Linked Adrenal Hypoplasia Congenita 24

Abe S, Nakae J, Shinohara N, Murashita M, Fujieda K Hokkaido University School of Medicine, Japan

Human Steroidogenic Factor-1 (hSF-1) Modulates Estrogen Receptor-Mediated Stimulation of

StAR 25

Promoter Activity

Ramayya MS, Kino T, Segars JH, Strauss III JF, Chrousos GP National Institute of Health, USA

Diabetes

BCG Vaccine Modulates Autoimmune Process in Newly Diagnosed IDDM Patients (Preliminary Report) $\quad 26$

Vazeou A, Lafferty K, Pergantou E, Spanos E, Gazda L, Bartsocas C University of Athens, Greece

Both Prepubertal and Pubertal Duration of Diabetes Affect the Incidence of Diabetic Retinopathy 27

Holl RW, Lang G, Heinze E, Lang GK, Teller WM University Children’s Hospital, Ulm,

Germany

Insulin Pulsatility in Children with Obesity 28

Nathwani N, Hindmarsh PC, Matthews DR, Brook CGD The Middlesex Hospital, London, UK Recombinant Human IGF-I (rhIGF-1) Improves Metabolic Control in Adolescents and Young Adults with IDDM 29

Quattrin T, Thrailkill K, Baker L, Kuntze J, Bajamonde A, Martha JRP Children's Hospital of Buffalo, USA

VII

Abstract No.

Allelic Effects of the INS 5' VNTR on IGF2 Expression in vitro and in vivo in Humans 30

Deal CL, Giannoukakis N, Polychronakos C, Paquette J, Vafiadis P Sainte Justine Hospital, University of Montreal, Canada

Mechanisms of Cytokine-Induced B-Cell Destruction: Up-Regulation of NO-Synthase and Activation of 31

the Fas Pathway

Zumsteg U, Frigerio S, Christen E, Wyss V, Hollander G University Children's Hospital Basel, Switzerland

16:00-17:00 Medical Controversy: Transition of the Adolescent Growth Hormone Deficient Patient to Adult

Endocrinology - How and When?

Transfer from the Paediatric Endocrinologist32

Stanhope R

Great Ormond Str., Hospital for Children, UK

Transition of the GHd Paediatric Patients to Adult Endocrinology - How and When?

Christiansen J Sandahl, Jörgensen JOL, Vahl N, Juul A, Müller J, Skakkebaek NE Aarhus

University Hospital, Denmark

IGF-1 Therapy: Metabolic Effects

IGF-1 Therapy: Metabolic Effects 34

Underwood L 
University of North Carolina, USA

RhlGF-1 Therapy: Metabolic Effects 35

Dunger DB

University of Oxford, UK

Clinical Research Methods: In vivo Microdialysis

Microdialysis: A Method for in vivo Steady-State Metabolic Studies in Humans 36

Ungerstedt $U$

Karolinska Institute, Stockholm, Sweden

Microdialysis in Pediatric Endocrinology and Metabolism 37

Marcus C

Huddinge Hospital, Sweden

17:30-18:30 Plenary Lecture

Leptin, Leptin Receptor and the Control of Body Weight 38

Friedman JM

Howard Hughes Medical Institute, USA

Tuesday, June 24 Plenary Lecture

08:30-09:30 Glucocorticoid Receptors: Structure and Function 39

Carlstedt-Duke, J Huddinge Hospital, Sweden

11:00-12:30 Mechanisms of Insulin Secretion and Action

Regulation of Insulin Release 40

Berggren PO

Karolinska Hospital, Stockholm, Sweden

Insulin Resistance 41

Wallberg-Henriksson $\mathrm{H}$

Karolinska Hospital, Stockholm, Sweden

Signaling through the Insulin and IGF-1 Receptor 42

Van Obberghen E

Faculté de Médecine, INSERM, Nice, France

Short and Long Term Treatment of Recombinant Human Insulin-Like Growth Factor (IGF)-I in

a Patient 43

with Leprechaunism

Murashita M, Nakae J, Kato M, Shinohara N, Tajima F, Abe S, Fujieda K Hokkaido University

School of Medicine, Japan

Genetic Disorders in Steroid Synthesis

Phenotype-Genotype Relationships in 21-Hydroxylase Deficiency 44

Wedell A

Karolinska Hospital, Stockholm, Sweden

VIII

Abstract No.

Insulin-Like Growth Factor (IGF-I) Inhibits Myogenin Promoter Activity through Element(s)

Contained within 60 the Sequence-94 to -9 of the Myogenin Gene

Adi S, Zhang P, Wu NY, Mellon SH, Rosenthal SM University of California, San Fransisco, USA

In vitro and in vivo Studies on the Role of Insulin-Like Growth Factor Binding Protein-3, -4 and -5 on 61

Bone Formation 
Kanzaki S, Mohan S, Ono T, Matsuoka Y, Moriwake T, Tanaka H, Seino Y Okayama University Medicine School, Japan

Heterogeneity of Hypochondroplasia 62

Grigelioniené G, Eklöf O, Anvret M, Hagenäs L Karolinska Hospital, Stockholm, Sweden

Thyroid/Bone

Thyroid Function of VLBW Neonates 63

Klein RZ, Faix JD, Frank JE, Nelson JC, Mitchell ML Dartmouth Medical School, USA

Juvenile Hyperthyroidism (JH): Long Term Treatment with Low Doses of Methimazole (MM). 64

When Should It Be Stopped?

Iorcansky S, Guercio G, Challer E Hospital de Pediatria Garrahan, Argentina

Different Impact of Antenatal and Postnatal Factors on Outcome in Congenital Hypothyroidism 65

Toublanc JE, Daubin C, Rives S, Toublanc JE Hôpital Saint-Vincent-de-Paul, France

Functional Characterization of Ca2+-Sensing Receptor Mutation Causing Sporadic

Hypoparathyroidism 66

De Luca F, Ray K, Mancilla EE, Fan G, Winer KK, Spiegel AM, Baron J Devel. Endocrinology

Branch, NIH, USA

Exon 2 Polymorphism in the Vitamin D Receptor (VDR) Gene and Early Exposure to Sex

Steroids Are 67

Major Determinants of Peak Bone Mineral Density (BMD)

Minamitani K, Takahashi Y, Minagawa M, Yasuda T, Niimi H Chiba University School of

Medicine, Japan

Bone Mineral Density in Children with Central Precocious and Early Puberty (CPP) during

Treatment 68

with GnRH Agonist

Boot AM, Engels MAMJ, Mul D, De Muinck Keizer-Schrama SMPF Sophia Children's

Hospital, The Netherlands

16:00-17:00 Medical Controversy: Use of hGH for Promotion of Growth in Normal Short

Children

Use of hGH Promotion of Growth in Normal Short Children - the Swedish Experience 69

Albertsson-Wikland $\mathrm{K}$

Sahlgrenska University Hospital, Sweden

Use of GH for Promotion of Growth in ISS Children: Final Height Results of the US Study 70

Hintz RL, Attie K, Johanson A, Baptista J, Kuntze J, Blizzard R, Cara J, Chernhausek S, Geffner M, Gertner J, Hopwood N, Kaplan S, Lippe B, Plotnick L, Rogol A, Rosenfield R, Aenger P, Leboeuf G, Roche A Stanford University Medical Center, USA

Controversies in Pediatric Endocrinology: Use of HGH for Promotion of Growth in Normal

Short Children. $\quad 71$

'It Does Not Make Them Taller Adults'

Brämswig J Münster, Germany

Medical Controversy: Results of Treatment of Central Precocious Puberty

Many Children with Central Precocious Puberty (CPP) Profit from Treatment with GnRH

Agonists 72

Sippell WG Kiel, Germany 
Considerations for the Cautious Use of GnRH Agonist Analogs in Girls with Idiopathic Central Precocious 73

Puberty

Kletter GB Seattle, USA

$\mathrm{X}$

Abstract

Clinical Research Methods: Measurement of Body Composition

Non-DEXA Methods 74

BierD

Baylor College of Medicine, Houston, USA

Measurement of Body Composition - Dual X-Ray Absorptiometry and Quantitative Ultrasound Approaches 75

Glüer C-C Kiel, Germany

17:30-18:30 Plenary Lecture

New Genes for Boys 76

Sinclair AH

University of Melbourne, Australia

Wednesday, Plenary Lecture

June $25 \quad$ Molecular Defects in the Chondrodysplasias 77

08:30-09:30 Rimoin DL, Wilcox W, Cohn D

Cedars-Sinai Med Center, Los Angeles, USA

11:00-12:30 Water Homeostasis: ADH and Aquaporins

The Aquaporin Family of Water Channels 78

Agre P, Nielsen S

Johns Hopkins School of Med, Baltimore, USA

ADH Gene Mutations 79

Richter D

University of Hamburg, Germany

The Vasopressin Regulated Water Channel Aquaporin-2 80

Nielsen S, Marples D, Frökiaer J, Christensen B, Agre P, Knepper M University of Aarhus,

Denmark

Environmental Effects on Male Reproduction

Trends in Male Reproductive Health: Paediatric Aspects 81

Skakkebaek NE, Toppari J

National University Hospital, Copenhagen, Denmark

Environmental Hormone Disruptors: Occurrence and Mechanisms of Action

Mc Lachlan J

Tulane/Xavier, Center for Bioenvironmental Research, New Orleans, USA

Environmental Antiandrogens: Mechanisms of Action

Kelce WR

Research Triangle Park, USA

Prenatal Diagnosis and Treatment of Endocrine Disease

Prenatal Diagnosis of Sex Chromosome Abnormalities and Post-Natal Management

Ratcliffe S

Institute of Children's Health, UK

Prenatal Diagnosis and Treatment of Congenital Adrenal Hyperplasia (CAH) 
Forest M, Morel Y, David M Hôpital Debrousse, France

Ethical Issues Arising in the Prenatal Diagnosis and Treatment of Endocrine Disease

Clarke A

University Hospital of Wales, UK

Scandinavian Experience of Prenatal Treatment of Congenital Adrenal Hyperplasia with

Dexamethasone 87

Hoist M, Lajic S, Wedell A, Ritzén EM, Knudzon J Karolinska Hospital, Stockholm, Sweden

Abstract No.

14:00-15:30 Sex Differentiation and Gonads

Survey of 241 Cases of Complete and Partial Androgen Insensitivity Syndrome (CAIIS and PAIS) 88

Ahmed SF, Batch JA, Bevan C, Davies HA, Dovey LA, Hawkins JR, Patterson MN, Rowland J, Shimura N, Williams DM, Hughes IA University of Cambridge, UK

17-Beta-Hydroxysteroid Dehydrogenase 3 (17HSD3) Deficiency in the Netherlands: Mutation and 89

Phenotypic Spectrum, Diagnostic Pitfalls

Boehmer ALM, Brinkmann AO, Niermeijer MF, De Jong FH, Otten BJ, Delemarre HA, Brunner HG, Drop SLS Sophia Children's Hospital, Rotterdam, The Netherlands

Trafficking of Androgen Receptor Fused to GFP in Living Cells: Application to Physiopathology of Androgen 90

Insensitivity Syndrome

Sultan C, Georget V, Terouanne B, Lobaccaro JM, Poujol N, Lumbroso S Hôpital A de

Villeneuve, Montpellier, France

Deletion Mapping of the Y Chromosomal Genes Involved in the Development of Turner Syndrome 91

Ogata T, Muroya K, Fukami M, Rappold G, Nakahori Y, Matsuo N Keio University, Japan

Pediatric Adrenocortical Tumors: Structural DNA Abnormalities and Insulin-Like Growth

Factor-11 92

Overexpression as Early Tumor Events

Gagni N, Paquette J, Oligny L, Van Vliet G, Deal C Sainte Justine Hospital, University of

Montreal, Canada

Treatment with a LH-RH Analogue following Successful Orchiopexy Markedly Improves the

Chance of 93

Fertility Later in Life

Hadziselimovic F, Herzog B Children's Hospital, Basel, Switzerland

Growth Factors II

Free Insulin-Like Growth Factor-I Levels Generally Reflect GH Secretion Status during

Childhood, Except for 94

Early Infancy and Acute Diseases

Hasegawa Y, Hasegawa T, Anzoh M, Aso T, Nanao K, Yamada M, Fujii K, Kotoh S, Tsuchiya

Y Tokyo Metropolitan Kiyose Children's Hospital, Japan

Ternary Complex Formation Determines the Growth Response to Growth Hormone (GH) in GH

Deficient 95

Children

Mandel SH, Moreland E, Rosenfeld RG, Gargosky SE Oregon Health Sciences University, USA 
Effects of LHRH-Analog (LHRH-A)-Induced Pubertal Delay in Growth Hormone Deficient Children Treated 96 with Growth Hormone: Results of a Randomized, Placebo-Controlled Trial

Cassorla F, Mericq V, Eggers M, Avila A, Garcia C, Fuentes A, Rose SR, Cutler GB University of Chile, Chile

Hormones and Apoptosis 1. High Apoptosis in Subjects with Growth Hormone Deficiency (GHD) 97

Dacou-Voutetakis C, Tsangaris GTH, Tzortzatou-Stathopoulou F, Voutetakis A ‘Aghia Sophia' Children's Hospital, Greece

Inhibition of Apoptosis by Insulin and Insulin-Like Growth Factor I in Human Hair Follicles 98

Batch J, Cain MA, Cann, CH

Royal Children's Hospital, Melbourne, Australia

Effects of Fibroblast Growth Factor on Skeletal Growth 99

Baron J, Mancilla EE, De Luca F, Czerwiec FS, Uyeda JA National Institutes of Health, USA

Regulation of Fat Tissue

Multiple Effects of Melanocortin Agonists and Antagonists on Insulin Secretion and Glucose

Metabolism 100

in the Lethal Yellow Mouse

Boston BA, Blaydon KM, Cone RD Oregon Health Sciences University, USA

Receptors for Melanin-Concentrating Hormone (MCH), a Neuropeptide Regulating Food Intake 101

Eberle AN, Drozdz R, Hintermann E, Zumsteg U, Jäggin V University Hospital, Basel,

Switzerland

XII

Abstract No.

Testosterone Treatment in Adolescents with Delayed Puberty: Effects on Protein Turnover,

Leptin and 102

Body Composition

Suprasongsin C, Aarslanian S University of Pittsburgh, USA

Circadian Rhythm of Leptin Relates to Body Size 103

Pringle PJ, Fall CHD, Matthews DR, Hindmarsh PC University College, London, UK

Cord Leptin Concentrations at Delivery - a Marker of Fetal Growth? 104

Geary M, Pringle PJ, Persaud M, Wilshin J, Hindmarsh PC, Rodeck CH, Brook CGD University

College, London, UK

Partial GH Deficiency and Changed Leptin Sensitivity due to Cranial Irradiation Contribute to

Overweight 105

after Childhood ALL/NHL

Mayer EIE, Wiedenmann SC, Dopfer RE, Elmlinger MW, Ranke MB University Children's

Hospital, Tubingen, Germany

16:00-17:00 Medical Controversy: GnRH Agonist (with or without GH) Treatment for

Precocious Puberty

and/or Short Stature

Combined GnRH Analog and GH Treatment in Short Children with Early Puberty for Height 106

Tanaka T 
Nat. Children's Med Res Center, Tokyo, Japan

Combined Treatment with GH and GnRH-Analogue in Adopted Girls with Precocious or Early

Puberty 107

Tuvemo T

Uppsala University Children's Hospital, Sweden

Luteinizing Hormone-Releasing Hormone Agonist (LHRHa)-lnduced Delay of Epiphyseal

Fusion Increases 108

Adult Height of Adolescents with Short Stature

Cutler GB, Yanovski JA, Rose SR, Filmer KM, Municchi G, Pescovitz OH, Hill SC, Cassorla

FG National Inst of Child Health \& Hum Dev, USA

Medical Controversy: Clinical Management of Abnormal Sex Differentiation

Management of Males with 45, X/46, XY Gonadal Dysgenesis 109

Müller J, Ritzén EM, Rajpert-De Meyts E, Skakkebaek NE Rigshospitalet, Copenhagen,

Denmark

Feminizing Genitoplaiy: When and How? 110

Nihoul-Fékété C, Lortat Jacob S, Josso N, Rappaport R Hôpital des Enfants Malades, France

Clinical Research Methods: Biochemical and Genetic Indices of GH Sensitivity

Biochemical Markers of Growth Hormone Sensitivity 111

Rosenfeld RG

Oregon Health Sciences University, USA

How, and How Hard, Should We Look for Mutated Growth Genes?

Parks JS

Emory University School of Med, Atlanta, USA

XIII 